\title{
ІНТЕРАКТИВНІ ТЕХНОЛОГІЇ ЗАОЧНОГО НАВЧАННЯ СТУДЕНТІВ-ФАРМАЦЕВТІВ
}

\author{
Л. М. Бурова \\ Львівський національний медичний університет імені Данила Галиџького

\section{INTERACTIVE TECHNOLOGIES OF CORRESPONDENCE LEARNING OF STUDENTS-PHARMACEUTISTS}

\section{M. Burova}

\author{
Lviv National Medical University by Danylo Halytskyi
}

\begin{abstract}
У статті обгрунтовано можливості використання поряд (замість) традиційної письмової контрольної роботи студентів заочної форми навчання виконання її із залученням інтерактивних методів.
\end{abstract}

The article adduces the possibilities of using instead of (or in the same time) traditional written test for students of correspondence learning, fulfilment of it involving the interactive methods.

Вступ. Система заочного навчання в Україні існує вже майже 100 років. Найбільший розвиток заочне навчання отримало саме у сфері вищої освіти. За достатньо великий період існування у системах освіти багатьох країн заочне навчання дозволило отримати освіту мільйонам людей, а сама система заочного навчання має достатній досвід у сфері форм організації і методики проведення занять, тестування, розроблення спеціалізованих навчальних посібників тощо. Головна перевага даної форми навчання - соціальна і полягає у можливості здобувати освіту незалежно від місця проживання, без відриву від роботи; застосувати свої знання під час навчання на практиці. Однак, окрім вищезазначених переваг, дана форма навчання має і деякі суттєві недоліки, найголовнішими $\epsilon$ такі: відсутність контакту між викладачем і студентом заочного навчання; обмеженість можливостей організації консультаційної допомоги студентам у період навчання; відсутність спілкування між студентами-однокурсниками; відсутність серед методів навчання групових дослідницьких чи проектних робіт; зведення самостійної роботи студента в основному до виконання письмових контрольних робіт [1].

Необхідність інтеграції України у світовий соціальний простір, зміни на ринку праці, реформи в системі освіти, де на зміну традиційній прийшла болонська система, потребують перегляду підходів до підготовки спеціалістів у вищій школі та моніторингу ефективності здійснюваних заходів. Відтак необхідно відшукати такі методи навчання, які б сприяли успі- шному засвоєнню студентами-заочниками знань, а також відповідали сучасним вимогам. Крім того, сучасна освітня система повинна трансформуватися в аспекті підготовки особистості, здатної до творчості, у процесі якої студент буде не пасивним об'єктом, а активним суб'єктом, який готує себе не лише до певного фаху, а й до активної участі у соціокультурних перетвореннях [2].

Основна частина. У ринкових умовах висока якість підготовки спеціаліста є одним із визначальних факторів знаходження ним свого місця на ринку праці та подальшого професійного зросту. Професійне самоусвідомлення набуває важливого значення для професійного становлення майбутнього фахівця і має свій специфічний зміст, який включає сукупність професійних знань, вмінь і навичок з фахових та фундаментальних дисциплін, зокрема рівня власної професійної компетентності, знання умов професійного самовдосконалення. Професійне самоусвідомлення дає можливість молодому фахівцю стати конкурентоспроможною особистістю в умовах сучасного ринку, який орієнтується на високу якість результатів праці. Професійне самоусвідомлення - це розуміння себе, своїх дій, норм, моделей поведінки, згідно з ідеалом та вимогами майбутньої професійної діяльності, а також оцінка себе як фахівця (задоволення або незадоволення результатами своєї професійної діяльності). В якості однієї з педагогічних методик формування професійного самоусвідомлення майбутніх медиків останнім часом усе частіше використову-

(C) Л. М. Бурова 
ються інтерактивні технології (IT), що дають змогу докорінно змінити ставлення до об' єкта навчання, перетворивши його на суб'єкт. Мета застосування інтерактивних методів полягає не тільки в спонуканні студентів до активної самостійної роботи, а й ініціюванні їх творчості, розвитку комунікативних навичок тощо [3]. Особливої уваги заслуговує врахування унікальних можливостей IT, реалізація яких створює передумови для небувалої в історії дидактики інтенсифікації навчального процесу, а також створення методик, орієнтованих на розвиток особистості тих, хто навчається. До таких можливостей відносяться: комп'ютерна візуалізація навчальної інформації про об'єкти або закономірності реальних та віртуальних явищ; миттєвий зворотний зв'язок між користувачем та інформаційними й комунікативними технологіями; архівне зберігання великих обсягів інформації з можливістю їі передавання, а також легкий доступ користувача до центральної бази даних; автоматизація процесів обчислювальної, інформаційно-пошукової діяльності; автоматизація інформаційно-методичного забезпечення та організаційного керування навчально-виховним процесом і контролю за його якістю. Суть методу полягає у виконанні студентами різних видів завдань навчального, виробничого, дослідницького і самоосвітнього характеру, які виступають як засіб засвоєння системи наукових та професійних знань, способів пізнавальної діяльності, формування навичок, умінь, досвіду творчої діяльності і професійної майстерності, позитивного ставлення до професії та навколишнього середовища, суттєвою ознакою якого є залучення інформаційного забезпечення інтернет-ресурсів кафедрального сайту. Цінність організації самостійної роботи студентів із залученням інтернет-ресурсів кафедрального сайту полягає в тому, що за умови педагогічно правильної організації і методичного дозування самостійна робота студентів дозволяє значно інтенсифікувати процес формування інформаційно-пошукових комунікативних умінь, надає навчальному процесу практично-орієнтований та проблемно-дослідницький характер, забезпечує самостійне рішення цілісної системи завдань, що мають прикладну спрямованість. Ця технологія сприяє максимальній активності студентів у пошуку нового, прагненню до самоосвіти, бажанню до професійного зростання. Завдяки цій технології є можливість забезпечити кожного студента необхідними джерелами інформації, за допомогою яких можна розширити обсяг знань, причому не тільки на базі текстових або графічних матеріалів, комп'ютера, але й посиланням на іншу літера- туру та методи отримання цієї інформації, i сформулювати необхідні вміння під час перевірки, оцінювання і коригування ходу навчання. При цьому ставляться освітні цілі: сприяння засвоєнню навчальних планів та програм у повному обсязі; послідовне вироблення навичок самостійної роботи в різних сферах діяльності; розвиток у студента пізнавальних мотивів, готовності до самонавчання, рефлексивних вмінь та критичного мислення. Навчальні завдання полягають у: закріпленні, узагальненні та повторенні навчального матеріалу; пристосуванні отриманих знань у стандартних ситуаціях та під час вирішення задач високого рівня складності та невизначеності; вдосконалення предметних вмінь та навичок за дисципліною; формування міжпредметних, загальнонавчальних та дослідницьких вмінь; активізування навчальної та науково-дослідницької діяльності студентів; формування готовності студентів до самоосвіти протягом всього життя [4].

Впроваджуючи інтерактивні технології навчання для студентів заочної форми навчання, а саме в розробку контрольних робіт, які студенти виконують у міжсесійний період, можна спробувати замінити традиційні теоретичні контрольні питання та прості типові ситуаційні задачі на більш сучасні - проблемні, 3 використанням деяких сучасних інтерактивних методів.

1. Метод проблемних ситуацій. Проблемною називають ситуацію, для оволодіння якою студент має знайти й застосувати нові для себе знання чи способи дій. У навчальному закладі пропонується створити банк даних або “кейс" проблемних ситуацій, який використовується у навчальному процесі для підготовки студентів до вирішення реальних проблем на виробництві (складних випадків з виробничої практики). Студентам роздаються необхідні для роботи матеріали та формулюється основна проблема. Вони мають оцінити ситуацію й розробити шляхи виходу 3 неї [5].

2. Метод “Навідних запитань”. Даний метод передбачає таку постановку запитання, при якій воно відіграватиме роль сильного імпульсу до дії, замінюючи вказівки. Складені викладачем запитання мають бути структурою проблемної теми, що має допомогти студенту приймати правильні самостійні рішення $[6,7]$.

3. Метод “Навідні тексти”. Головний принцип даного методу, що опирається на тексти, полягає в тому, що студент навчається, а викладач інструктує його. В межах професійного навчання цей метод використовується для підготовки, виконання та наступ- 
ного аналізу результатів практичної діяльності, тобто студент може аналізувати особистий досвід і в процесі навчання упевнено вирішувати, яким шляхом краще досягти поставленої мети $[6,7]$.

4. Метод проектної роботи. Проектна робота це комплексна робота з теми професійного навчання з використанням проектних методів, ії застосовують з метою розвитку в студентів здібностей планувати, самоорганізовуватися, а також піднести їхню соціальну компетентність. Теми проектних робіт мають бути пов' язані з професійною діяльністю й містити теоретичні та практичні проблеми $[6,7]$.

5. Метод розкриття теми через ланияюжок заnuтань. Даний метод використовується для розкриття складних для розуміння студентами тем, які охоплюють значну кількість навчальних проблем. Студенти йдуть шляхом пізнання, орієнтуючись на цілу низку запитань, підготовлених викладачем [6, 7].

6. Метод зіткнення з реальними робочими ситуаціями. Даний метод ставить за мету навчання, здебільшого теоретичну підготовку до праці у майбутньому, а говорячи про студентів заочної форми навчання, не лише в майбутньому, а й в теперішньому часі. Набуття практичного досвіду роботи під час участі в реальному виробничому процесі. Цей метод передбачає наступне: студенту доручається робоче завдання, для виконання якого в нього немає повної фахової компетенції, всі прогалини в знаннях та вміннях студент має заповнити інтуїтивно, спонтанно [6, 7].

Для виконання таких нетипових контрольних робіт необхідно створити студентам-заочникам сучасний навчальний процес з усіма атрибутами, а саме: мож-

\section{Література}

1. Калєніченко Л. І. Заочне та дистанційне навчання: порівняльний аналіз / Л. I, Калєніченко. - http:// archive.nbuv.gov.ua/portal/soc_gum/vkhnuvs/2009_47/47/ 38.pdf

2. Зайцев М. О. Впровадження кредитно-модульної системи організації навчального процесу як чинник реформування освіти в контексті Болонського процесу: проблеми та прогнози / М. О. Зайцев // Збірник методичних матеріалів та рекомендацій для молодих викладачів з організації та планування навчально-методичної роботи. - Харків, 2006. $-836 \mathrm{c}$.

3. Пометун О. Сучасний урок. Інтерактивні технології навчання : науково-методичний посібник / О. Пометун, Л. Пироженко. -К. : Видавництво “А.С.К.”, 2004. - 194 с. ливістю та необхідністю роз'яснення навчального матеріалу викладачем (у форумі, через електронну пошту чи програму SKYPE); можливістю спілкування викладач-студент та студент-студент протягом усього міжсесійного періоду навчання; можливістю проведення обговорень, тестування, поточних іпідсумкових робіт, виконання спільних завдань, а також завдань дослідного і творчого характеру тощо [1].

Висновок. У сучасних умовах велика роль у всьому світі надається інформатизації навчального процесу, впровадженню й поширенню нових інформаційних технологій навчання, формуванню основ інформаційної культури студентів, їх підготовці до життя в сучасному інформатизованому суспільстві, вмінню працювати з сучасною комп'ютерною технікою. Тому доцільним було б замінити традиційне написання контрольних робіт студентами-заочниками на виконання контрольних робіт з введенням інтерактивних технологій та використанням визначених методів (проблемних ситуацій, проектних робіт тощо). На допомогу студентам заочної форми навчання слід залучити комунікаційні технології (комп'ютерні телекомунікації, супутниковий зв'язок, аудіо- та відеотехнологіi), які дозволяють забезпечувати постійний зв'язок між учасниками навчання (викладачів-студентів, студентів-студентів) у режимі реального часу, незважаючи на географічну віддаленість один від одного. При цьому передбачається активна участь у діалозі обох сторін: обмін питаннями та відповідями, контроль за виконанням прийнятих рішень. Отже, використання нових методів інтерактивних технологій навчання повинно забезпечити якісне навчання та всебічний інтелектуальний розвиток сучасної людини.

4. Учебное пособие для студ. пед. вузов и системы повыш. квалиф. пед. кадров / Е. С. Полат, М. Ю. Бухаркина, М. В. Моисеева, А. Е. Петров ; под ред. Е. С. Полат. - М. : Издательский центр “Академия”, 2002. -272 с.

5. Ситуационный анализ, или Анатомия Кейс-метода / под ред. Д-ра социологических наук, профессора Ю. П. Сурмина. -Киев : Центр инноваций и развития, 2002. - 286 с.

6. Інновації в педагогічній освіті європейського простору: матеріали Міжнародної науково-практичної конференції, 27-28 вересня 2009 року. - Полтава, 2009. - С. 374 379.

7. Носков В. И. Инновационные технологии в гуманитарном вузе / В. И. Носков, А. В. Кальянов. - Донецк : ООО Лебедь, 2002. 